\title{
The Presence of Japanese Encephalitis Virus Infection in Pteropus sp. in West Kalimantan
}

\author{
Saepulloh M, Dharmayanti NLPI, Adjid RMA, Ratnawati A, Sendow I \\ Indonesian Research Center for Veterinary Science \\ Jl. RE Martadinata No. 30, Bogor 16114, West Java, Indonesia \\ indrawati.sendow@yahoo.com
}

\begin{abstract}
Japanese Encephalitis (JE) is one of zoonotic arboviruses which cause encephalitis in human and is transmitted by mosquitoes. Fruit bat is one of the natural reservoir of JE. The aim of this study was to determine the prevalence of JE reactor in fruit bats. A total of 70 bat sera was obtained from West Kalimantan. Those sera were tested against JE antibody using an ELISA test. The results indicated that $4.2 \%$ of bat sera were positive against JE virus. The results indicated the importance of fruit bat is a reservoir host for a JE virus. Hence further prevention in public health must be considered and the detection and identification of JE virus should be conducted for molecular characteristic in relation to use appropriate vaccine in the country.
\end{abstract}

Key Words: Fruit Bats, Japanese Encephalitis, Antibody, ELISA

\section{INTRODUCTION}

Japanese encephalitis (JE) virus is an important member of the arthropod-borne Flavivirus genus of the Flaviviridae family. The virus has an envelope, a single-stranded, positive sense RNA genome. The virus is antigenically related to several other flaviviruses, including the dengue virus.

The natural hosts are domestic and wild vertebrate animals. Domestic and migrating birds as well as pigs are effective amplifying hosts, and humans are infected occasionally. Fruit bats is also recognised as a reservoir host for JE. Fruit bats, Pteropus sp genus plays an important role in transmitting the zoonotic agent. Hence it will be a world attraction to carry emerging and re-emerging diseases. Further information, JE is a strategic zoonotic disease which has high priority according to WHO.

$\mathrm{JE}$ is transmitted to animals and human by mosquitoes. Culex tritaenirochynchus, had been prooved to be the primary vector for $\mathrm{JE}$ and it prefers to breed in irrigated rice paddies and feed on pigs (Zheng et al. 2012; Le Flohic et al. 2013). Some species of Culex including $C x$. tritaenirochynchus, Cx. quinquefasciatus, Cx. Fuscocephalus that may act as suspected potential vector of JE, had been found in Indonesia (Hadi et al. 2011). Pig farms and the environmental condition of JE vector breeding sites are also found through out Indonesia.

In human, the virus targets is the central nervous system and produces clinical signs initially as fever, headache, abdominal pain, nausea, and vomiting. After several days the neurological symptoms appear as encephalitis, meningitis, movement disorders and generalized weakness until progressive confusion, delirium, conciousness and coma (CDC 2013; Fischer, 2013).

The infection can result in high mortality, especially in children less than 15 years old (Diagana et al. 2007; Tripathi et al. 2016). Even the clinical symptome in human is very low, but the mortality in human can be up to $40 \%$ after showing the clinical signs and if the patient survived, it will produce persistent neurologic or psychological sequelae (CDC 2013; Fischer, 2013; Tripathi et al. 2016). 
The disease can be prevented by vaccination and the antibody responses produced is life-time (Desai et al. 2012; Halstead \& Thomas 2010). Antibody against JE virus can be detected using serological tests such as HI or ELISA test which are widely used (Tripathi et al. 2016).

In Indonesia, clinical case had been reported in human, in pigs serologically detected and $\mathrm{JE}$ virus had been isolated in vector. However, JE antibody and virus prevalence in bats or wild animals has not been reported in Indonesia. This study investigated the seroprevalence of JE in fruit bats (Pteropus sp.) in West Kalimantan Province. The results is useful for the the government policy especially in locating pig farms.

\section{MATERIAL AND METHODS}

\section{Sample collection}

Blood from fruit bat, genus Pteropus. were collected from bats seller or bat's buyers at Peniti Luar Village, sub district Siantan, Mempawah District, West Kalimantan Province. Serum was then seperated in a local laboratory. The bats were kept between 1-2 days before sampling. Only the mature bats for both female and male were sampling. Long armed bats were also measured for identification. In total of 70 sera of Pteropus sp. were collected from some bats seller or bat collectors in Peniti Village, Mempawah District in West Kalimantan Province in 2015. Interview to the bat sellers was conducted related to the clinical disease they got and treatment.

Serum samples were transported to Indonesian Research Center for Veterinary Science (IRCVS), Bogor using the cold chained system then preserved at $-20^{\circ} \mathrm{C}$ in IRCVS Serum Bank for further testing using ELISA test.

\section{Japanese Encephalitis ELISA test}

Japanese Encephalitis Elisa test was performed under the methods of Lunt (2014). The test is able to detect antibody of JE virus. The inactive JE virus antigen and Monoclonal antibody of JE were provided from Australian Animal Health Laboratory, Geelong Australia. In IRCVS laboratory, the test was set up accordingly the protocol of Lunt (2014).

\section{RESULTS AND DISCUSSION}

A total of 70 sera of Pteropus sp were collected from West Kalimantan Province and bats had long armed between 19-21 cm. Based on the long armed and consult with the bats expert through bats photograph it is probably Pt. vampyrus (Field, pers.com)

The interview to the bats selers and collector was conducted during the survey and indicated that they had been biten by the bats during collection ,but had never shown clinical signs as JE infection including headache, encephalitis. The clinical sign was not also observed in their family. Serological results revealed that $3(4,2 \%)$ of 70 bats serum were positives for JE antibody as shown in Table 1. Meanwhile, in previous study JE infection had been reported in other species included cattle, goat, horse, dog duck, chicken and pig serologically. The prevalence varied from 11 to $51 \%$ depend on the location (Sendow et al. 2003; 2000; Kumara et al. 2013).

Sentinel surveillance of JE has identified human cases in Bali, Kalimantan, Java, Nusa Tenggara, Papua, and Sumatra based on CDC (2015). So far the source of infection of human cases undetermined. Our result also detected some positive serum sampel of bats 
and of pig from Kalimantan, and based on CDC (2015) there were also positive JE in human in Kalimantan. Hence there might be a correlation between positive JE in human and the reservoir including pigs and bats. It is suggested that bats species in Kalimantan have a potential risk factor for JE and posibble transmit to human. Further study on its transmission must be conducted.

Table 1. Serological result of JE infection using ELISA test in bats in West Kalimantan 2015

\begin{tabular}{lccc}
\hline \hline Location & No. Samples & Positive & $\%$ \\
\hline Peniti Luar Village, Siantan Subdistrict, & 70 & 3 & 4.2 \\
Mempawah District, West Kalimantan Province & & & \\
\hline
\end{tabular}

In fruit bats as genus Pteropus, many zoonotic viruses have been detected. These including flaviviruses, alphaviruses, rhabdoviruses, arenaviruses, reoviruses dan paramyxoviruses (Field et al. 2007). On the other hands, Pteropus sp. had been prooved as a reservoir host for emerging and re-emerging diseases such as Nipah, Hendra and JE, which are fatal if infected to human (Playford et al. 2010).

In Asia, JE antibodies was detected in bats in China with the prevelance of $15 \%$ by ELISA and non of those brain sample was detected using q PCR in China (Jie et al. 2008). Furthermore a recent serological report from Chinese bats indicated that Rousettus leschenaultia, Miniopterus schreibersii, Pipistrellus abramus, and Rhinolophus macrotis had antibodies against JE virus which the prevalence varied from 30 to $95 \%$ depend on the species and region (Jiang et al. 2015).

Antibodies against JE can be detected using HI, serum neutralization and ELISA. Recently Shimoda et al. (2013) has reported that indirect ELISA can detected the JE antibody with sensitivity and specificity 82 and $98 \%$. In serology, JE antibody can be detected as group cross reactivity.

McKenzie et al. (2002) reported that there was a broad cross reaction between eight virus species and 2 subtypes flaviviruses including JEV, West Nile virus (WNV), Kunjin virus (a subtype of WNV), Murray Valley encephalitis virus (MVEV), Alfuy virus (a subtype of MVEV), St. Louis encephalitis virus (SLEV), Usutu virus (USUV), Koutango virus, Yaounde virus and Cacipacore virus. In this ELISA test, cross reaction with other flavivirus group was detected such as MVEV (Lunt 2014). However, MVEV was not reported in Indonesia. Hence we can assume that the antibody detected in the ELISA test in this study is due to JE infection.

On the genetic level, JE gene sequence from bats in China with the JE gene from gene bank, indicated that their genetic was similar and had high genetic homogenicity among their bats isolates in different geographical areas, in different times period and different species. Furthermore, those bat JEV isolates were also phylogenetically similar to JE isolated from mosquito and human. This results indicated that the bat JEV isolates might be evolutionarily conserved and bats might be involved in natural cycle of JEV in China (Liu et al. 2013).

Previous study using antigen detection in bats using conventional PCR indicated that from 25 brain bat samples collected from the same animal as used for serology, none of those is positive (Sendow unpublished data). Similar results of Jie et al. (2008) also indicated that no JE virus detected using realtime PCR. This may indicated that the infectious period in bats may be vey short therefore the possibility to detect the JE virus is very low. Other possibility is the bat is not infected by JE virus. Further followed up study should be conducted to detect the JE virus and to gain further information whether JE isolates from Indonesian bats were different to others. 
Previous study indicated that $84 \%$ of pig sera and $12 \%$ of P. vampyrus sera collected in 2006 in West Kalimantan Province reacted with Japanese encephalitis virus and flavivirus C-ELISA. None of the Cynopterus brachyotis collected showed evidence of infection (Sendow et al. 2008). Compared to those previous results in Kalimantan, the recent study showed the lower prevalence $(4.2 \%)$ of JE infection in bats, therefore there is a reduction of prevalence of $\mathrm{JE}$ infection in bats. There are some factors of the reduction on prevalence such as the $\operatorname{IgG}$ detected recently is decreased, the time and period of sample collection is not appropriate and geographically sampling could be different to previous collection. The samples collected in this study is only based on the information of the bats owner, bat's sellers or bar's collectors.

\section{CONCLUSION}

The study indicated that fruit bats can be naturally infected with JEV and have variable prevalence of JEV antibodies in their sera. The role of bats in the natural cycle of JEV awaits further study. Although it is still uncertain, based on the above findings, it can be concluded that bats may play an important role as a natural reservoir host for Japanese Encephalitis virus, and fruit bats can play as disseminators in viral circulation. Therefore, the potential threat of JEVcarrying bats to human health should be considered. To avoid human and pig infection, the contact of reservoir host and the animal such as pig should be minimized.

\section{ACKNOWLEDGEMENT}

The authors would like to thanks Dr Peter Daniels, Mr Ross Lunt from Australian Animal Health Laboratory, Geelong, Australia for providing the inactiveated JE andtigen and monoclonal antibody. Mr Heri Hoerudin, Mr Teguh Suyatno were also appreciated to help in the field and laboratory work. Our gratitude was also addressed to Head of Dinas Peternakan Provincy West Kalimantan and his staffs who help in the survey and provide the provincial laboratory and its facilities during the survey.

\section{REFERENCES}

CDC. 2012. Japanese encephalitis surveillance and immunization - Asia and the Western Pacific. Centers for Disease Control and Prevention. MMWR Morb Mortal Wkly Rep 2013. 62:658662.

CDC. 2011. Update on Japanese Encephalitis vaccine for childrend United States, May. Centers for Disease Control and Prevention. Morb Mortal Wkly Rep. 60:664-665.

CDC. 2013. Use of Japanese Encephalitis vaccine in children: Recommendations of the advisory committee on immunization practices. Centers for Disease Control and Prevention. Morb Mortal Wkly Rep. 62:898-900.

CDC. 2015. Japanese Encephalitis. Chapter 3. Infectious Diseases Related to Travel. Centers for Disease Control and Prevention. http://wwwnc.cdc.gov/trave1/yellowbook/2016/infectiousdiseases-related-to-travel/japanese-encephalitis. [accessed in 25 April 2016].

Desai K, Coudeville L, Bailleux F. 2012. Modelling the long-term persistence of neutralizing antibody in adults after one dose of live attenuated Japanese Encephalitis chimeric virus vaccine. Vaccine. 30:2510-2515.

Diagana M, Preux PM. 2007. Dumas, Japanese Encephalitis revisited. J Neurol Sci. 262:165-170. 
Fischer M. 2013. Japanese Encephalitis (JE) vaccine for U.S. travelers. Presentation to the Advisory Committee on Immunization Practices. Atlanta, GA. February 20, 2013. [Internet]. Available at: http://www.cdc.gov/vaccines/acip/meetings/downloads/slides-feb-2013/02-jevaccine-fischer.pdf.

Hadi UK, Soviana S, Syafriati T. 2011. Ragam jenis nyamuk di sekitar kandang babi dan kaitannya dalam penyebaran Japanese Encephalitis. J Vet. 12:326-334.

Halstead SB, Thomas SJ. 2010. Japanese Encephalitis: New options for active immunization. Clin Infect Dis. 50:1155-1164.

Hsu TC, Gao JQ, Lu KH, Tsai CH, Huang CY, Tzang BS. 2008. Japanese Encephalitis virus envelope protein mitigates TNF-alpha mRNA expression in RAW264.7 cells. Inflammation. 31:133-140.

Jiang L, Chen S, Zheng X, Ma S, Zhou J, Zhang Q, Li X, Xiong Y, Zhong X, Wang Z, Chen Q. 2015. Detection of serum antibodies against Japanese encephalitis virus in bats in Hainan and Guangdong Provinces of China. Nan Fang Yi Ke Da Xue Xue Bao. 35:720-723.

Jie C, Counor D, Shen D, Sun G, He H, Deubel V, Zhang S. 2008. Detection of Japanese Encephalitis virus antibodies in bats in Southern China. Am J Trop Med Hyg. 78:1007-1011.

Kumara MBAQ, Adi AAAM, Mahardika IGNK. 2013. Deteksi antibodi terhadap virus Japanese Encephalitis pada ternak babi di Wilayah Jembrana dan Klungkung. Indones Med Vet. 2:7684.

Le Flohic G, Porphyre V, Barbazan P, Gonzalez JP. 2013. Review of climate, landscape, and viral genetics as drivers of the Japanese Encephalitis virus ecology. PLoS Negl Trop Dis. 7:e2208.

Liu S, Li X, Chen Z, Chen Y, Zhang Q, Liao Y, Zhou J, Ke X, Ma L, Xiao J, Wu Y, Chen Z, Zhou J, Zheng X. Li J, Chen Q. 2013. Comparison of genomic and amino acid sequences of eight Japanese Encephalitis virus isolates from bats. Arch Virol. 158:2543-2552. DOI 10.1007/s00705-013-1777-5.

Lunt R. 2014. Japanese Encephalitis virus: competition ELISA test for the detection of serum antibodies. Australian Animal Health Laboratory Diagnosis, Surveillance and Response. Newcomb (Australia): CSIRO. p. 1-15.

McKenzie JS, Barrett AD, Deubel V. 2002. The Japanese Encephalitis serological group of Flaviviruses: A brief introduction to the group. Clin Microbiol Rev. 267:1-10.

Sendow I, Bahri S, Sarosa A. 2000. Prevalensi Japanese-B Encephalitis pada berbagai spesies di Indonesia, JITV. 5:46-52.

Sendow I, Syafriati T, Hadi UK, Malole M, Soviana S, Darminto. 2003. Epidemiology of Japanese-B Encephalitis infection in pigs in Riau and North Sumatera Provinces. JITV 8:6470.

Sendow I, Field HE, Adjid RMA, Lunt R, Ratnawati A, Breed AC, Darminto D, Mustafa AM. 2008. Seroepidemiology of Japanese Encephalitis virus infection in bats and pigs in West Kalimantan, Indonesia. Microbiol Indones. 2:79-82.

Shimoda H, Inthong N, Noguchi K, Terada Y, Nagao Y, Shimojima M, Takasaki T, Rerkamnuaychoke W, Maeda K. 2013. Development and application of an indirect enzymelinked immunosorbent assay for serological survey of Japanese Encephalitis virus infection in dogs. J Virol Methods. 187:85-89. DOI: 10.1016/j.jviromet.2012.09.022. Epub 2012 Oct 6.

Tripathi P, Kumar R, Jain A, Pramod W. Ramteke PW. 2016. Hospital based surveillance for Japanese Encephalitis in Lucknow, India - 2011-2013: Need for more JE vaccination? Clin Epid Global Hlth. 4:40-44.

WHO. (2015). Japanese Encephalitis vaccines: WHO position paper-February 2015. Wkly Epidemiol Rec. 90:69-88.

Zheng Y, Li M ,Wang H, Liang G. 2012. Japanese Encephalitis and Japanese Encephalitis virus in mainland China. Rev Med Virol. 22:301-322. 